\title{
Application of a liquid chromatographic method for the determination of phenolic compounds and furans in fortified wines
}

\author{
P. Ho*, T.A. Hogg, M.C.M. Silva \\ Universidade Católica Portuguesa, Escola Superior de Biotecnologia, Rua Dr. Antonio Bernardino de Almeida, Porto 4200, Portugal
}

\begin{abstract}
Fortified wines which suffer extended periods of wood ageing develop characteristics which in many cases define the product. An important component of this style is contributed by the specific phenolic compounds and furans which are either extracted from the wood or formed during the barrel ageing process. An HPLC method is presented here for the determination of phenolic compounds and furans in wood aged fortified wines. The method employed involved direct injection with no sample pre-treatment, separation on a $\mathrm{RP} \mathrm{C}_{18}$ column in a single run and detection with a diode array detector. In this way up to 28 compounds from various phenolic groups (hydroxybenzoic acids, hydroxycinnamic acids, phenolic aldehydes, coumarins, flavan-3-ols, flavonol aglycones) and other compounds involved in browning reactions in food systems (furans and pyranones) could be separated and determined. Of these, 10 phenolic compounds, gallic acid, protocatechuic acid, p-coumaric acid, caffeic acid, chlorogenic acid, ellagic acid, vanillic acid, syringic acid, $p$-hydroxybenzaldehyde, myricetin, and two furans; furfural, 5-hydroxymethyl-2-furaldehyde, were determined in fortified and similar wood aged wines. Three other compounds, a chlorogenic acid isomer, vanillin and resorcinol, were also tentatively identified in these wine types.
\end{abstract}

\section{Introduction}

Fortified wines are fermented or partly fermented wines which have been supplemented with distilled spirit of grape origin. These include products as diverse as port and madeira (Portugal), sherry (Spain), vins doux naturels (France) and various other products from Australia, South Africa or USA, which may or may not be produced to resemble the European products listed. Many fortified wines are produced in such a way that their composition enables them to withstand considerable ageing either in bottle or in wooden cask, the characteristics developed during this ageing being perceived as essential to their style. Tokay wines, which originate from Hungary, range from dry to sweet and are characterised by a large amount of extract, displaying characteristic flavour and aroma (Farkaš, 1988). Tokay Aszú wines, which are the best known of these wines, are aged for at least 4 years in wooden cask, their characteristics lead them to be considered in the same category as wood-aged fortified wines and for this reason they are included in this study.

\footnotetext{
* Corresponding author. Fax: + +351-2-590351; e-mail: peter@esb.ucp.pt
}

Phenolic compounds are the major substrates for the consumption of oxygen in wine, participating in many oxidation-reduction reactions (Singleton, 1987; Fabre, 1994). These compounds contribute directly or indirectly to colour (Ribéreau-Gayon, 1982), astringency and bitterness (Arnold and Noble, 1978; Robichaud and Noble, 1990), aroma (Chatonnet, 1993), and they are also involved in browning reactions in both grapes and wines (Macheix et al., 1991). Ageing of wines in wooden barrels can increase the pool of oxidisable phenolic substances through extraction of these compounds from the wood (Puech, 1987; Piergiovanni et al., 1988).

Browning reactions are known to occur during processing and storage affecting the flavour, appearance, and nutritive value of a product. Furans are a group of compounds that are formed during nonenzymatic browning reactions, such as caramelization, which involves the degradation of sugars, and the maillard reaction, involving amadori rearrangement compounds (Eskin, 1990). Furans have been found in both tawny ports (Williams et al., 1983) and in sherry (Shimizu and Watanabe, 1979), contributing to the brown colour of these wood-aged wines.

Work published in recent years have shown highperformance liquid chromatography to be the method 
of choice in the analysis of phenolic compounds present in wines. Due to the complex nature of these beverages, samples must be pretreated before analysis. Pretreatment methods which are mainly based on liquid-liquid extraction (Salagoity-Auguste and Bertrand, 1984; Estrella et al., 1986; Puech, 1987; Revilla et al., 1988; Woodring et al., 1990; Laszlavik et al., 1995) and solid phase extraction (Lunte et al., 1988; Oszmianski et al., 1988; Cartoni et al., 1991), can result in errors in estimating the true quantities present. The search for more accurate quantification methods have led researchers to develop direct injection techniques using diode array detection (Roggero et al., 1990; Lamuela-Raventos and Waterhouse, 1994; Goldberg et al., 1996), multi-wavelength detection combined with spectrofluorimetry (Moutounet et al., 1989), or electrochemical detection (Achilli et al., 1993). Although there is a great deal of information in the literature on phenolic compounds in table wines (Table 1), there is little on fortified wines. Of that which is reported most have focused on sherry (Estrella et al., 1986; Revilla et al., 1988; Guillén et al., 1993; Barón et al., 1997), although anthocyanins have been quantified in young port wines (Bakker and Timberlake, 1985). Apart from the lack of information on phenolic compounds in fortified wines, very few HPLC methods are concerned with the combined analysis of phenolic compounds and furans. Moutounet et al. (1989) used a direct injection method with multi-wavelength detection combined with spectrofluorimetry to determine these compounds in Chardonnay wine, while Estrella et al. (1986) using ultraviolet detection, analysed ethyl ether extracts of sherry wines. Combined HPLC analysis of both phenolic compounds and furans have also been developed for other biological substrates such as for maple products (Kermasha et al., 1995a) and apple juice (Kermasha et al., 1995b).

The objective of this study was to develop a HPLC technique suitable for analysing both phenolic compounds and furans in a variety of fortified wines. Samples were injected directly into the HPLC, without the need for sample pre-treatment, with phenolic compounds and furans identified using a diode array detector. The identification and quantification of these compounds are reported in Tawny port, Madeira, Amontillado sherry, Banguls and in Tokay Aszú wines.

\section{Materials and methods}

\subsection{Wines}

Wines analysed were tawny ports consisting of a Colheita 1990 and Colheita 1960 (Port wine with date of harvest), a 10 years old and a 30 years old Aged Tawny port (Port with indication of age). Other wines included a solera medium Amontillado sherry, a 10 years old
Verdelho madeira, a Banyuls Rimage 1989, a Banyuls 1977 (tawny type), a Tokay Aszú 5 puttonyos 1983 and a Tokay Aszú 4 puttonyos 1988.

\subsection{High performance liquid chromatography system}

All samples were analysed by direct injection on a Beckman System Gold ${ }^{(i x}$ High Performance Liquid Chromatography system (Beckman Instruments, Inc., Fullerton, CA, USA) equipped with a Beckman Model 168 Diode Array detector and Beckman model 502 autosampler. Beckman system Gold ${ }^{(m)}$ HPLC software version 6.01 was used for data acquisition and analysis. Phenolic compounds and furans were separated on a $250 \mathrm{~mm} \times 4.6 \mathrm{~mm}$ Spherisorb S5 ODS2 column (Phase separations Ltd, Clywd, UK) which was controlled at $25^{\circ} \mathrm{C} \pm 1$ using a temperature controlled Croco-Cil No. 726 Oven.

\subsection{Chromatographic conditions}

HPLC Separation conditions: Solvent A, water-formic acid (98:2); Solvent B, $700 \mathrm{ml}$ of methanol containing $2 \%$ formic acid with $300 \mathrm{ml}$ of Solvent A. Gradient elution program was: $3 \mathrm{~min}$ at $0 \% \mathrm{~B}$, to $10 \% \mathrm{~B}$ in $7 \mathrm{~min}$, to $40 \% \mathrm{~B}$ in $50 \mathrm{~min}$, to $60 \% \mathrm{~B}$ in $20 \mathrm{~min}$, to $100 \% \mathrm{~B}$ in $25 \mathrm{~min}, 15 \mathrm{~min}$ at $100 \% \mathrm{~B}$, return to initial conditions in

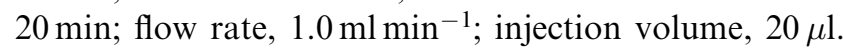
Phenolic compounds and furans were detected at $280 \mathrm{~nm}$ and $320 \mathrm{~nm}$.

\subsection{Peak characterisation and quantification}

Phenolic compounds and furans were characterised by their UV spectra which were recorded from $190 \mathrm{~nm}$ to $402 \mathrm{~nm}$ ( $2 \mathrm{~nm}$ steps). Peaks were identified by superimposing the spectra of each peak with the corresponding spectra of standard compounds, by the comparison of their retention times and in some cases by spiking the wine with pure standards. Quantification was based on peak areas as determined by Beckman System Gold ${ }^{\text {(ix }}$ HPLC software version 6.01 using external standards. Linear calibration curves for standards (peak area vs concentration) were constructed with $R^{2}$ exceeding 0.999 .

\subsection{Standards for peak characterisation}

Gallic acid, p-hydroxybenzoic acid, protocatechuic acid, gentisic acid, $p$-coumaric acid, caffeic acid, ferulic acid, ellagic acid, vanillic acid, syringic acid, vanillin, p-hydroxybenzaldehyde, syringaldehyde, (+)-catechin, (-)-epicatechin, esculin, esculetin, scopoletin, resorcinol, myricetin, quercetin, furfural, 5-methylfurfural, 5-hydroxymethyl-2-furaldehyde (HMF), maltol were purchased from Sigma. Chlorogenic acid and Salicylic acid (Merck), coniferaldehyde (Aldrich). 


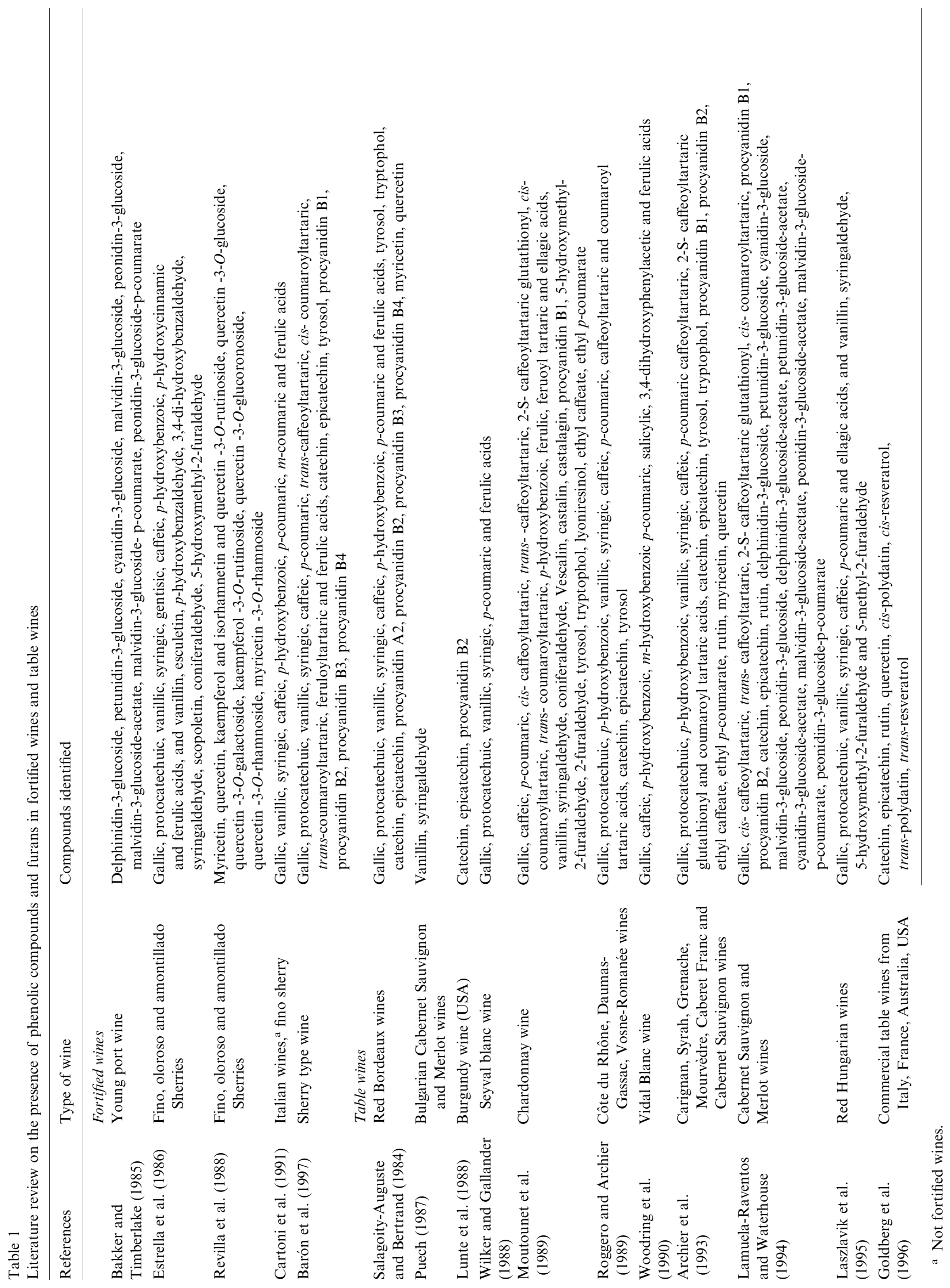




\section{Results and discussion}

\subsection{Method development}

The presented method was developed initially for the separation, identification and quantification of wood derived phenolic compounds, such as vanillin, syringaldehyde, vanillic acid and syringic acid, in fortified wines. It was based on a preparative HPLC method for the separation of wood derived phenolic compounds from an extract of oak wood (Puech et al., 1988). Initial results using this method showed many overlapping peaks with poor separation between compounds, such as vanillin and syringic acid. The optimisation of the separation of these compounds was achieved after experimenting with various gradient profiles, mobile phase flowrates and also different mobile phases, such as acetonitrile. During this period, it became apparent that the method could also be used for the separation of other phenolic compounds and also furans that were present in these wood-aged wines. These included resorcinol, an extractive of Quercus rubra (Seikel et al., 1971), and maltol, one of the most important carbohydrate degradation compounds derived from oak wood
(Sefton, 1991) and commonly associated with 5-hydroxymethyl-2-furaldehyde through the maillard reaction pathway. Up to 28 standard compounds could be separated and identified in a $20 \%$ ethanol-water mixture according to the criteria shown in Table 2. These included classes of phenolic compounds, such as hydroxybenzoic acids, hydroxycinnamic acids, phenolic aldehydes, coumarins, flavan-3-ols and flavonol aglycones, some of which are found only in wood-aged wines and spirits, and other compounds involved in browning reactions in food systems (furans and pyranones).

\subsection{Identification and quantification of phenolic compounds}

Fig. 1 shows the chromatographic profiles of phenolic compounds and furans in 5 different types of fortified wines and a naturally sweet wine. Thirteen phenolic compounds were identified (Table 3), 7 of which have been shown to be present in natural and toasted wood extracts (Laszlavik et al., 1995). The limit of detection and limit of quantification of these compounds, calculated as $3 \sigma$ and $10 \sigma$ above the peak to peak noise level (Analytical Chemistry, 1980), were very low (Table 4).

Table 2

Retention times and spectra characteristics of standard compounds investigated

\begin{tabular}{|c|c|c|c|c|c|}
\hline $\begin{array}{l}\text { Compound } \\
\text { no. }\end{array}$ & Name & $\begin{array}{l}\text { Retention time, Rt (min) } \\
\text { mean }^{\mathrm{a}} \pm \mathrm{SD}\end{array}$ & $\operatorname{RSD}(\%)^{\mathrm{b}}$ & $\begin{array}{c}\text { Spectral } \\
\lambda_{\max }(1)\end{array}$ & $\begin{array}{c}\text { characteristics } \\
\lambda_{\max }(2)\end{array}$ \\
\hline 1 & Gallic acid & $9.17 \pm 0.17$ & 1.80 & 270 & - \\
\hline 2 & Resorcinol & $10.61 \pm 0.07$ & 0.65 & 273 & - \\
\hline 3 & 5-Hydroxymethyl-2-furaldehyde (HMF) & $13.33 \pm 0.03$ & 0.26 & 283 & - \\
\hline 4 & Protocatechuic acid & $14.59 \pm 0.07$ & 0.50 & 293 & 258 \\
\hline 5 & Furfural & $16.80 \pm 0.06$ & 0.33 & 276 & - \\
\hline 6 & $p$-Hydroxybenzoic acid & $21.22 \pm 0.12$ & 0.59 & 252 & - \\
\hline 7 & Gentisic acid & $22.10 \pm 0.25$ & 1.12 & 328 & - \\
\hline 8 & Maltol & $22.58 \pm 0.12$ & 0.54 & 274 & - \\
\hline 9 & $p$-Hydroxybenzaldehyde & $26.16 \pm 0.20$ & 0.78 & 283 & - \\
\hline 10 & Esculin & $26.78 \pm 0.52$ & 1.93 & 332 & 294 \\
\hline 11 & $(+)$-Catechin & $27.62 \pm 0.45$ & 1.65 & 276 & - \\
\hline 12 & Vanillic acid & $29.99 \pm 0.09$ & 0.30 & 290 & 258 \\
\hline 13 & 5-Methylfurfural & $30.06 \pm 0.27$ & 0.89 & 291 & - \\
\hline 14 & Esculetin & $32.51 \pm 0.27$ & 0.84 & 344 & 296 \\
\hline 15 & Caffeic acid & $33.72 \pm 0.26$ & 0.76 & 322 & 294 \\
\hline 16 & Chlorogenic acid & $35.94 \pm 0.22$ & 0.61 & 324 & 298 \\
\hline 17 & Vanillin & $37.18 \pm 0.30$ & 0.81 & 308 & 278 \\
\hline 18 & Syringic acid & $38.44 \pm 0.24$ & 0.62 & 274 & - \\
\hline 19 & $(-)$-Epicatechin & $42.56 \pm 0.24$ & 0.56 & 276 & - \\
\hline 20 & $p$-Coumaric acid & $45.39 \pm 0.08$ & 0.17 & 310 & - \\
\hline 21 & Syringaldehyde & $45.51 \pm 0.04$ & 0.09 & 306 & - \\
\hline 22 & Salicylic acid & $48.06 \pm 0.17$ & 0.35 & 300 & - \\
\hline 23 & Ferulic acid & $53.55 \pm 0.31$ & 0.59 & 342 & 296 \\
\hline 24 & Scopoletin & $53.70 \pm 0.62$ & 1.16 & 322 & 296 \\
\hline 25 & Coniferaldehyde & $57.77 \pm 0.39$ & 0.68 & 338 & 302 \\
\hline 26 & Ellagic acid & $80.18 \pm 0.12$ & 0.15 & 366 & 290 \\
\hline 27 & Myricetin & $80.35 \pm 0.40$ & 0.50 & 370 & 266 \\
\hline 28 & Quercetin & $89.07 \pm 0.10$ & 0.11 & 370 & 266 \\
\hline
\end{tabular}

a Mean of retention times \pm standard deviations for 4 replicates.

b Relative standard deviations of retention times (\%). 
In most cases the older wines of the same type, the Colheita ports, Aged Tawny ports and the tokay wines, had a higher concentration of total identified phenolic compounds. As a group of wines, the tawny ports had more wood derived phenolic compounds than all the others. Ellagic acid and vanillin, tentatively identified by comparison to the retention time of standards, were found only in these wines. Vanillic acid, syringic acid, protocatechuic acid and ellagic acid were present in higher concentrations in the older wines of the two styles
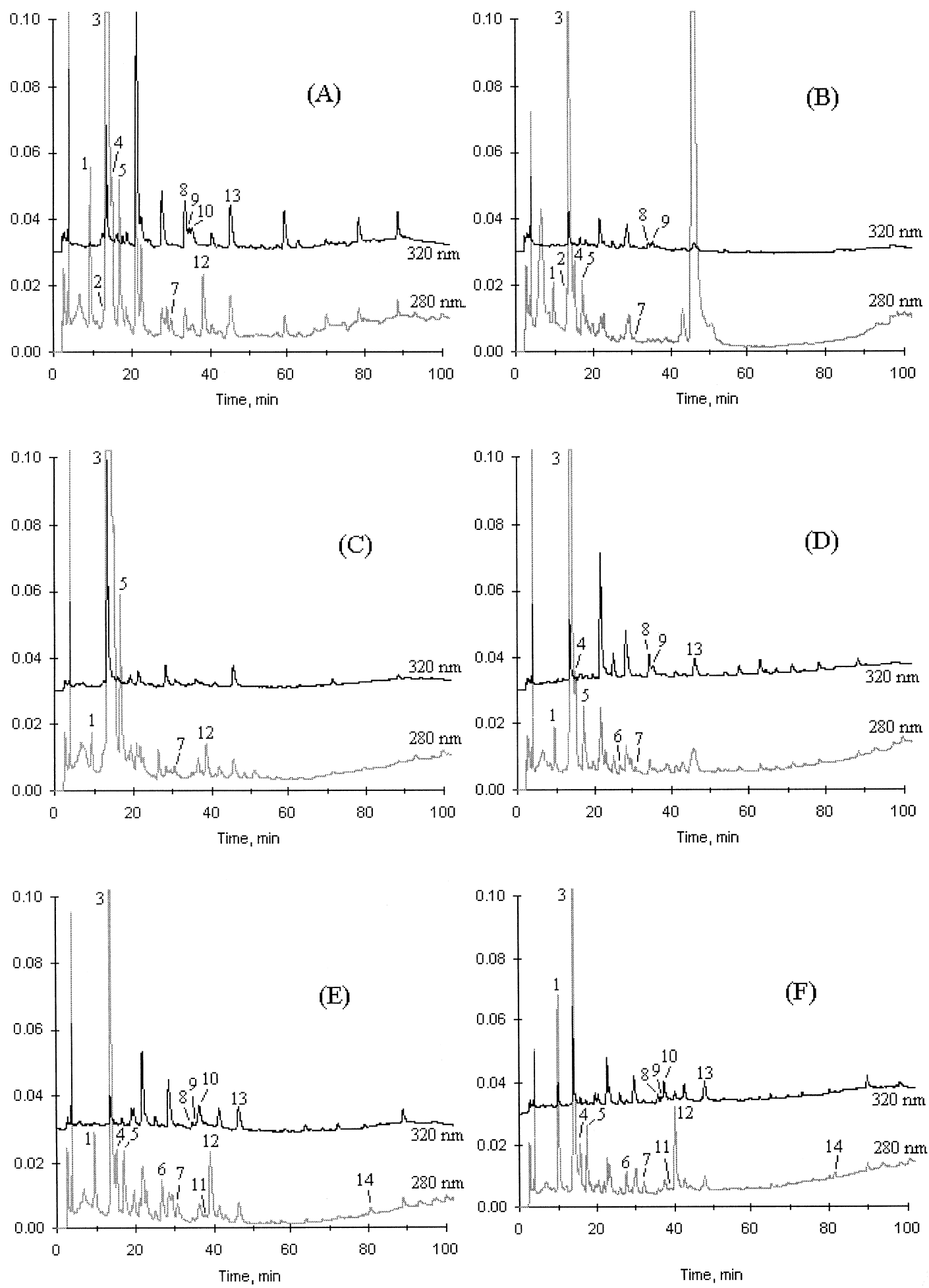

Fig. 1. Chromatographic profiles of phenolic compounds and furans in different fortified wines. (A), Banyuls 1977; (B), Tokay 1983; (C), 10 years old Madeira; (D), Amontillado sherry; (E), Tawny port Colheita 1960; (F), 10 years old Tawny port. Peak numbers are identified in Table 3. 
Table 3

Concentration of phenolic compounds and furans identified in various fortified wines $\left(\mathrm{mg} \mathrm{l}^{-1}\right)$

\begin{tabular}{|c|c|c|c|c|c|c|c|c|c|c|c|}
\hline $\begin{array}{l}\text { Peak } \\
\text { no. }\end{array}$ & Wines & $\begin{array}{c}\text { Port } \\
10 \text { years }\end{array}$ & $\begin{array}{c}\text { Port } \\
30 \text { years }\end{array}$ & $\begin{array}{l}\text { Port } \\
1990\end{array}$ & $\begin{array}{l}\text { Port } \\
1960\end{array}$ & Sherry & $\begin{array}{l}\text { Madeira } \\
10 \text { years }\end{array}$ & $\begin{array}{c}\text { Tokay } \\
1988\end{array}$ & $\begin{array}{c}\text { Tokay } \\
1983\end{array}$ & $\begin{array}{c}\text { Banyuls } \\
1989\end{array}$ & $\begin{array}{c}\text { Banyuls } \\
1977\end{array}$ \\
\hline 1 & Gallic acid & 27.0 & 30.5 & 13.6 & 12.1 & 5.2 & 5.3 & 4.0 & 5.3 & 32.8 & 22.3 \\
\hline 2 & Resorcinol $^{\mathrm{a}}$ & - & - & - & - & - & - & 1.9 & 2.1 & $\operatorname{tr}$ & $\operatorname{tr}$ \\
\hline 3 & 5-Hydroxymethyl-2-furaldehyde & 33.2 & 168.7 & $\operatorname{tr}$ & 35.5 & 86.8 & 361.0 & 19.5 & 42.9 & $\operatorname{tr}$ & 162.4 \\
\hline 4 & Protocatechuic acid & 13.9 & 20.2 & 3.0 & 9.2 & 7.2 & - & 4.3 & 7.7 & 5.1 & 13.5 \\
\hline 5 & Furfural & 3.5 & 7.8 & 0.8 & 3.8 & 2.9 & 8.8 & 0.8 & 1.8 & - & 8.7 \\
\hline 6 & $p$-Hydroxybenzaldehyde & $\operatorname{tr}$ & 0.6 & $\operatorname{tr}$ & 0.9 & $\operatorname{tr}$ & - & - & - & $\operatorname{tr}$ & - \\
\hline 7 & Vanillic acid & 3.0 & 4.6 & 4.5 & 5. 6 & 1.5 & 3.6 & 1.3 & 1.2 & 4.5 & 5.0 \\
\hline 8 & Caffeic acid & 1.2 & 1.5 & 1.4 & 1.1 & 2.3 & - & 1.1 & 0.9 & 3.9 & 4.6 \\
\hline 9 & Chlorogenic acid isomer ${ }^{\mathrm{a}}$ & 1.1 & 0.8 & 2.4 & 1.0 & 2.1 & - & 2.3 & 2.0 & 2.8 & 1.8 \\
\hline 10 & Chlorogenic acid & 5.1 & 4.4 & 12.8 & 6.1 & - & - & - & - & 2.0 & 3.0 \\
\hline 11 & Vanillin ${ }^{\mathrm{a}}$ & $\operatorname{tr}$ & 0.4 & - & 0.2 & - & - & - & - & - & - \\
\hline 12 & Syringic acid & 8.6 & 10.6 & 8.0 & 8.6 & - & 4.2 & - & - & 7.6 & 8.2 \\
\hline 13 & $p$-Coumaric acid & 2.7 & 3.0 & 3.3 & 4.2 & 3.4 & - & - & - & 6.5 & 6.5 \\
\hline 14 & Ellagic acid & 2.4 & 3.1 & 3.3 & 3.7 & - & - & - & - & - & - \\
\hline \multirow[t]{3}{*}{15} & Myricetin & - & - & - & - & - & - & - & - & 4.5 & - \\
\hline & Total phenolic compounds & 65 & 79.7 & 52.3 & 52.7 & 21.7 & 21.9 & 14.9 & 19.2 & 69.7 & 64.9 \\
\hline & Total furans & 36.7 & 176.5 & 0.8 & 39.3 & 89.7 & 369.8 & 20.3 & 44.7 & $\operatorname{tr}$ & 171.1 \\
\hline
\end{tabular}

tr, trace amounts below the limit of quantification (LOQ); - , not detected, below the limit of detection (LOD).

a Tentatively identified.

Table 4

Detection limits of identified phenolic compounds and furans

\begin{tabular}{lcc}
\hline Compound & $\begin{array}{r}\text { Limit of } \\
\text { detection } \\
(\mathrm{LOD}) \\
\left(\mu \mathrm{g} \mathrm{I}^{-1}\right)\end{array}$ & $\begin{array}{c}\text { Limit of } \\
\text { quantification } \\
(\mathrm{LOQ}) \\
\left(\mu \mathrm{g} \mathrm{I}^{-1}\right)\end{array}$ \\
\hline Gallic acid & 1.95 & 4.87 \\
Resorcinol & 0.54 & 1.36 \\
5-Hydroxymethyl-2-furaldehyde & 5.66 & 14.15 \\
Protocatechuic acid & 3.25 & 8.13 \\
Furfural & 0.74 & 1.85 \\
$p$-Hydroxybenzaldehyde & 5.50 & 13.76 \\
Vanillic acid & 1.13 & 2.83 \\
Caffeic acid & 3.41 & 8.54 \\
Chlorogenic acid & 1.49 & 3.74 \\
Vanillin & 4.53 & 11.32 \\
Syringic acid & 3.85 & 9.62 \\
$p$-Coumaric acid & 3.74 & 9.36 \\
Ellagic acid & 0.75 & 1.88 \\
Myricetin & 9.84 & 24.61 \\
\hline
\end{tabular}

of tawny ports examined. Gallic acid was in much higher concentrations in Aged Tawny ports than the Tawny Colheita ports. The presence of higher concentrations of these phenolic compounds in the older wines may have been the result of their extraction from wood during ageing. However, a previous study demonstrated that phenolic compounds, such as gallic acid, syringic acid, vanillic acid and protocatechuic acid, can increase in table wine aged in bottle for nine months as the result of the degradation of tannins (Archier et al., 1993). It is likely that some of the differences in the concentration of phenolic compounds were caused by both wood extraction and the degradation of tannins.
$p$-Hydroxybenzaldehyde was found in trace quantities in the Banyuls 1989, the Amontillado sherry and in all of the tawny ports. Myricetin was found only in the Banyuls Rimage 1989 and a compound eluting very closely to HMF in both Tokay and Banyuls wines, was tentatively identified as resorcinol, an extractive of Quercus rubra (Seikel et al., 1971). To the best of our knowledge, this is the first time resorcinol has been identified in wood-aged wines. The identification was based on the spectral characteristics and retention time of a commercial standard. Peak 9 was tentatively identified as a chlorogenic isomer as it had identical spectral characteristics to chlorogenic acid. Isomers of chlorogenic acid have been identified previously in apple juice and in tobacco (Court, 1977; Spanos et al., 1990).

Many phenolic compounds, including some coumarins and phenolic aldehydes (Table 1), which have been found in wood-aged table wines (Achilli et al., 1993) and sherry (Estrella et al., 1986), were not found in the wines analysed. Coumarins, such as scopoletin, has been found at a concentration of $15.5 \mu \mathrm{g}^{-1}$ in a diethyl ether extract from a red wine aged in new wood using fluorescence detection (Salagoity-Auguste et al., 1987). Their presence as trace quantities in wines would have made them undetectable by the UV method that had been developed.

Oxidation of phenolic compounds, such as syringaldehyde and vanillin, to their corresponding acids (Puech, 1981), or the oxidation of caffeic acid under acidic condition to tetrahydrofuran derivatives (Fulcrand et al., 1994), may limit their presence in the wines analysed. Certain hydroxycinnamic acids like ferulic acid can also be converted to 4-vinylguaiacol by yeast 
when a wine is aged in old barrels (Chatonnet et al., 1992), which may explain its absence in the wines analysed.

\subsection{Identification and quantification of furans}

5-Hydroxymethyl-2-furaldehyde (HMF) and furfural were identified in all of the wines analysed, although furfural was not found in the Banyuls Rimage 1989. The younger wines had lower amounts of both furans than the older wines indicating the importance of these compounds in the ageing process. Furfural has been known to increase during the bottle ageing of Riesling wines (Simpson, 1980) and in wood-aged Italian wines (Stefano, 1988). The amounts of furfural found in this study ranged from as low as $0.8 \mathrm{mgl}^{-1}$ in the tawny colheita port 1990 to $8.8 \mathrm{mg}^{-1}$ in the 10 years old Verdelho madeira.

HMF in tawny ports was on average much higher than previously found in tawny port wines by Williams et al. (1983). The 10 years old Verdelho madeira had the highest concentration of HMF probably not so much as the result of wood ageing, but mainly from the Estufagem process, which is a three month maturation period at around $41^{\circ} \mathrm{C}$ (Goswell et al., 1977). The concentrations of HMF and furfural found in the Amontillado sherry, although slightly higher, were very close to the ones found previously by gas chromatography (Shimizu and Watanabe, 1979). 5-methylfurfural which has been identified in Australian tawny port wines (Simpson, 1980) and Tokay Aszú wines (Schreier et al., 1976) by gas chromatography was not identified in the wines analysed in this study.

\section{Conclusions}

HPLC with diode array detection has shown the presence of a number of wood derived phenolic compounds and furans in a range of different dessert wines. Phenolic composition varied in terms of class, number and the concentration of individual compounds identified. The presence of higher concentrations of total phenolic compounds and furans in older wines, as in the case of the tawny ports, suggests that wood ageing plays an important role in the evolution of these compounds. However, the degree of importance of the role of oxidation, interaction and degradation of these compounds with time, and the extraction of these compounds from wood in the ageing of fortified wines needs to be studied further.

\section{Acknowledgements}

P.H. was supported by a grant from the Commission of the European Communities DG XII. Science, research and development (Contract No. ERBAIR1CT925114).

\section{References}

Achilli, G., Cellerino, G. P., Gamache, P. H. and D'Eril, G. V. M. (1993) Identification and determination of phenolic constituents in natural beverages and plant extracts by means of a coulometric electrode array system. Journal of Chromatography 632, 111-117.

Analytical Chemistry (1980) Guidelines for data acquisition and data evaluation in environmental chemistry. Analytical Chemistry, 52, 2242-2249.

Archier, P., Coen, S. and Roggero, J.-P. (1993) Changes in the phenolic content of single-variety wines after the first nine months of storage. Science des Aliments 13, 483-489.

Arnold, R. A. and Noble, A. C. (1978) Bitterness and astringency of grape seed phenolics in a model wine solution. Am. J. Enol. Vitic. 29, 150-152.

Bakker, J. and Timberlake, C. F. (1985) The distribution and content of anthocyanins in young port wines as determined by high performance liquid chromatography. Journal of the Science of Food and Agriculture 36, 1325-1333.

Barón, R., Mayén, M., Mérida, J. and Medina, M. (1997) Changes in phenolic compounds and browning during biological aging of sherry-type wine. Journal of Agricultural and Food Chemistry 45, $1682-1685$.

Cartoni, G. P., Coccioli, F., Pontelli, L. and Quattrucci, E. (1991) Separation and identification of free phenolic acids in wines by highperformance liquid chromatography. Journal of Chromatography 537, 93-99.

Chatonnet, P. (1993) Fenoli volatili: influenze organolettiche e metodi di prevenzione. Vigne Vini. 20, 26-34.

Chatonnet, P., Dubourdieu, D., Boidron, J. N. and Pons, M. (1992) The origin of ethylphenols in wines. Journal of the Science of Food and Agriculture 60, 165-178.

Court, W. A. (1977) High-performance liquid chromatography of naturally occurring phenolic compounds. Journal of Chromatography 130, 287-291.

Eskin, N. A. M. (1990) Biochemistry of food processing: Browning reactions in foods. In Biochemistry of Foods, ed. N. A. M. Eskin, 2nd Edition, pp. 239-296. Academic Press, London.

Estrella, M. I., Hernández, M. T. and Olano, A. (1986) Changes in the polyalcohol and phenol compound contents in the ageing of sherry wines. Food Chemistry 20, 137-152.

Fabre, S. (1994) Destination de l'oxygène consommé par le vin. Rev. Enologues. 71, 23-26.

Farkaš, J. (1988) Production of dessert and naturally sweet wines. In Technology and Biochemistry of Wine, ed. J. Farkaš, Vol. 2, pp. 427443. Gordon and Breech Pub, Switzerland.

Fulcrand, H., Cheminat, A., Brouillard, R. and Cheynier, V. (1994) Characterization of compounds obtained by chemical oxidation of caffeic acid in acidic conditions. Phytochemistry 35, 499-505.

Goldberg, D. M., Tsang, E., Karumanchiri, A., Diamandis, E. P., Soleas, G. and Ng, E. (1996) Method to assay the concentrations of phenolic constituents of biological interest in wines. Analytical Chemistry 68, 1688-1694.

Goswell, R. W. and Kunkee, R. E. (1977) Fortified Wines. In Economic Microbiology, ed. A. H. Rose, Vol. 1: Alcoholic Beverages, pp. 477-503. Academic Press, London.

Kermasha, S., Goetghebeur, M. and Dumont, J. (1995a) Determination of phenolic compound profiles in maple products by high-performance liquid chromatography. Journal of Agricultural and Food Chemistry, 43, 708-716.

Kermasha, S., Goetghebeur, M., Dumont, J. and Couture, R. (1995b) Analyses of phenolic and furfural compounds in concentrated and non-concentrated apple juices. Food Research International 28, 245 252.

Lamuela-Raventos, R. M. and Waterhouse, A. L. (1994) A direct HPLC separation of wine phenolics. Am. J. Enol. Vitic. 45, 1-5. 
Laszlavik, M., Gál, L., Misik, S. and Erdei, L. (1995) Phenolic compounds in two Hungarian red wines matured in Quercus robur and Quercus petrea barrels: HPLC analysis and diode array detection. Am. J. Enol. Vitic. 46, 67-74.

Lunte, S. M., Blankenship, K. D. and Read, S. A. (1988) Detection and identification of procyanidins and flavanols in wine by dualelectrode liquid chromatography-electrochemistry. Analyst 113, 99-102.

Macheix, J. J., Sapis, J. C. and Fleuriet, A. (1991) Phenolic compounds and polyphenoloxidase in relation to browning in grapes and wines. CRC Crit. Rev. Food Sci. Nutr. 30, 441-486.

Moutounet, M., Rabier, P., Puech, J.-L., Verette, E. and Barillere, J.M. (1989) Analysis by HPLC of extractable substances in oak wood. Application to a Chardonnay wine. Science des Aliments 9, 35-51.

Oszmianski, J., Ramos, T. and Bourzeix, M. (1988) Fractionation of phenolic compounds in red wine. Am. J. Enol. Vitic. 39, 259-262.

Piergiovanni, L., Fava, P. and Volonterio, G. (1988) Il vino in barrique. Vini d'Italia. 30, 17-28.

Puech, J.-L. (1981) Extraction and evolution of lignin products in Armagnac matured in oak. Am. J. Enol. Vitic. 32, 111-114.

Puech, J.-L. (1987) Extraction of phenolic compounds from oak wood in model solutions and evolution of aromatic aldehydes in wines aged in oak barrels. Am. J. Enol. Vitic. 38, 236-238.

Puech, J.-L., Rabier, P. and Moutounet, M. (1988) Preparative separation by high-performance liquid chromatography of an extract of oak wood and the determination of the composition of each fraction. Jurnal of Chromatography 457, 431-436.

Revilla, E., Alonso, E. and Estrella, M. I. (1988) Analysis of flavonols in wines by HPLC. In Frontiers of Flavor, ed. G. Charalambous, pp. 711-728. Elsevier Science Publishers, Amsterdam, Netherlands.

Ribéreau-Gayon, P. (1982) The anthocyanins of grapes and wines. In Anthocyanins as Food Colors, ed. P. Markakis, pp. 209-244. Academic Press.

Robichaud, J. L. and Noble, A. C. (1990) Astringency and bitterness of selected phenolics in wines. Journal of the Science of Food and Agriculture 53, 343-353.

Roggero, J.-P. and Archier, P. (1989) Mis au point d'une méthode de dosage des phénols simples des vins application a des vins d'origines et d'ages différents. Conn. Vigne et Vin 23, 25-37.

Roggero, J.-P., Coen, S. and Archier, P. (1990) Wine phenolics: optimization of HPLC analysis. Journal of Liquid Chromatography 13, 2593-2603.
Salagoity-Auguste, M. H. and Bertrand, A. (1984) Wine phenolicsanalysis of low molecular weight components by high performance liquid chromatography. Journal of the Science of Food and Agriculture 35, 1241-1247.

Salagoity-Auguste, M. H., Tricard, C. and Sudraud, P. (1987) Dosage simultané des aldéhydes aromatiques et des coumarines par chromatographie liquide haute performance. Journal of Chromatography 392, 379-387.

Schreier, P., Drawert, F., Kerenyi, Z. and Junker, A. (1976) Gaschromatographisch-massenspecktrometrische untersuchung fluechtiger inhaltsstoffe des Weines. VI. Aromastoffe in Tokajer Trockenbeerenauslese(Aszu)-Weinen. (a) Neutralstoffe. Zeitschrift für Lebensmitteluntersuchung und -forschung 161, 249-258.

Sefton, M. A. (1991) How does oak barrel maturation contribute to wine flavor?Practical Winery and Vineyard XII 4, 17-20.

Seikel, M. K., Hostettler, F. D. and Niemann, G. J. (1971) Phenolics of Quercus rubra wood. Phytochemistry 10, 2249-2251.

Shimizu, J. and Watanabe, M. (1979) Gas chromatographic analysis of furfural and hydroxymethylfurfural in wine. Agric. Biol. Chem. 43, 1365-1366.

Simpson, R. F. (1980) Volatile aroma components of Australian port wines. Journal of the Science of Food and Agriculture 31, 214-222.

Singleton, V. L. (1987) Oxygen with phenols and related reactions in musts, wines and model systems: observations and practical implications. Am. J. Enol. Vitic 38, 69-77.

Spanos, G. A., Wroldtad, R. E. and Heatherbell, D. A. (1990) Influence of processing and storage on the phenolic composition of apple juice. Journal of Agricultural and Food Chemistry 38, 15721579.

Stefano, R. (1988) The volatile compounds of wood-aged wines. Vini d'Italia 30, 9-18.

Wilker, K. L. and Gallander, J. F. (1988) Comparison of Seyval blanc wine aged in barrels and stainless steel tanks with oak chips. Am. J. Enol. Vitic. 39, 38-43.

Williams, M. A., Humphreys, R. C. and Reader, H. P. (1983) The analysis 5-hydroxymethylfurfural in Port by High Performance Liquid Chromatography. Am. J. Enol. Vitic. 34, 57-60.

Woodring, P. J., Edwards, P. A. and Chisholm, M. G. (1990) HPLC determination of non-flavonoid phenols in Vidal blanc wine using electrochemical detection. Journal of Agricultural and Food Chemistry 38, 729-732. 